\title{
Effect of Aerobic Exercises on Plasma Adiponectin Level in Type 2 Diabetic Patients
}

\author{
Ahmed KHASHABA
}

Associate Professor of Medical Physiology, RIYADH ELM University, Riyadh- Kingdom of Saudi Arabia

*Correspondence - ahmedkhashaba@riyadh.edu.sa

\begin{abstract}
Objective: To examine the effect of aerobic exercises on plasma adiponectin and HbA1c levels in type 2 diabetic patients. Material and Methods: 136 patients with type 2 diabetes (age between 22 and 77 years) recruited from the outpatient clinics, Kasr Alaini, Egypt were randomly allocated into two groups. Group A $(n=63)$ was the control group which followed only medication and diet program while group B $(n=73)$ was the study group which followed the medication, diet program and performed aerobic treadmill exercise at moderate $(50-80 \%$ of $\mathrm{VO} 2 \mathrm{max}$ by $50 \%$ of maximum heart) three times per week for six weeks. Blood samples of plasma adiponectin were taken and recorded before and after the completion of the exercise program. Results: Adiponectin levels were elevated following the exercise program of moderate intensity (study $5.84 \pm .09$ versus control $5 \pm .2 \mathrm{ug} / \mathrm{mL}$ ). In comparison to baseline, adiponectin levels (study $4.12 \pm .22 \mathrm{versus}$ control $4.07 \pm .183$ $\mathrm{ug} / \mathrm{mL}$ ). Conclusion: Moderate intensity aerobic exercise result in a significant increase in plasma adiponectin levels in type 2 diabetic patients
\end{abstract}

Keywords: adiponectin, diabetic, moderate aerobic exercises.

\section{Introduction}

Adiponectin is a protein has anti-diabetic, anti-inflammatory and anti-atherogenic effects and secreted by adipose tissue. Diabetes may be associated with Hypoadiponectinemia. ${ }^{[1]}$ Insulin resistance is inversely related to plasma adiponectin levels. ${ }^{[2]}$

The relationship between an acute bout of aerobic exercise and adiponectin levels in is still unclear. ${ }^{[3]}$ Exercise can increase plasma adiponectin in $38 \%$ of RCTs. adiponectin levels increase after short-term exposure to aerobic or resistance training of moderate-to-high intensities. ${ }^{[4]}$

It is also unclear whether one week of aerobic exercise training can increase the plasma adiponectin levels in individuals with abdominal obesity. ${ }^{[3]}$

Two studies have examined adiponectin levels immediately after exercise in inactive, abdominally obese individuals and report that adiponectin levels are decreased ${ }^{[5]}$ or unchanged. ${ }^{[6]}$

Adiponectin levels can be significantly elevated after 1 week (two to three bouts) of moderately intense exercise. Short-term moderate exercise training can regulate adiponectin and reduces atherogenic risk. $^{[2]}$

Glycosylated hemoglobin (HbA1c) can be decreased by exercise. ${ }^{[7]}$

Regular aerobic exercise intervention for 8 weeks has statistically and clinically significant effect on $\mathrm{HbAlc}$ and improved glycemic control. ${ }^{[8]}$

Exercises have many effects on increasing VO2peak, decreasing of $\mathrm{HbA} 1 \mathrm{c} \%$, decreasing of subcutaneous visceral abdominal fat and increasing of mid-tight muscle. More vigorous aerobic exercise programs have greater reductions in $\mathrm{HbA1c}$, and greater increase in insulin sensitivity ${ }^{[9]}$

\section{Materials and Methods}

The study was conducted from january 2017 to january 2018 at kasr Alaini Hospital, Egypt. The study was designed as a prospective randomized clinical trial.

136 patients with type 2 diabetes between 22 and 77 years of age referred to the outpatient clinics, who were diagnosed with type 2 diabetes, were enrolled in the study. Patients with severe diseases and advanced diabetic complications such as neuropathy or retinopathy, history of cerebrovascular incidents, orthopedic problems, cancer, age $>80,<20$ years, taking insulin, $\mathrm{BMI}>35$, hbA1c value $>11$, surgical interventions in the brain, upper or lower limbs were excluded from the study. Written informed consent was obtained from each patient. Age, sex, diagnosis, comorbidities, plasma adiponectin, HbA1c of patients beside basic demographic data of the subjects were recorded for each group.

Patients were randomized into 2 groups. In group A was the control group and was treated through diet control and medication and didn't perform any exercise and group B was the study group and was treated through the same selected program of diet control and medication in addition to designed aerobic exercise training program of moderate intensity. All treatments were applied for 3 days a week, $30 \mathrm{~min}$, at a moderate intensity and $50-80 \%$ of VO2max by $50 \%$ of maximum heart rate for 6 weeks by the same physician. Plasma adiponectin and HbA1c levels was recorded for all subjects at baseline and after 12 weeks.

\section{Results}

\section{Statistics}

A statistical package program was used to evaluate the data obtained from the study. Descriptive statistical methods (frequency, proportion, mean, and standard deviation) were used in the evaluation of research data as well as the KolmogorovSmirnov distribution test for examining normal distribution. The 


\section{International Journal of Innovative Research in Medical Science (IJIRMS) \\ Volume 03 Issue 05 May 2018, ISSN No. - 2455-8737 \\ Available online at - www.ijirms.in}

Pearson chi-square test was used in comparing qualitative data. In comparing quantitative data, the unpaired samples t-test was used in intergroup comparison of parameters. The Paired samples t-test was used for intragroup comparisons. Pearson product moment correlation coefficient was used to determine the correlations between Plasma adiponectin and HbAlc levels post treatment in the study group. The results were calculated at the $95 \%$ confidence interval, $\mathrm{P}<0.05$ significance level and $\mathrm{P}<0.01$ advanced significance level.

Baseline characteristics of the patients are shown in Table 1. The control group included 34 females and 29 males patients and The study group included 39 females and 34 males patients. The average age was $49.87 \pm 15$ years in the control group and $53.63 \pm 13.99$ years in the study group.

No side effects or complications were observed during the treatment. Baseline characteristics of the patients are shown in Table 1.

No statistically significant difference was found between the 2 groups in terms of age and sex $(\mathrm{P}>0.05)$.

The increase in the plasma adiponectin for the control group at the end of the treatment was statistically not significant in comparison to baseline $(\mathrm{P}>0.05)$, as shown in Table 2 .

The increase in the plasma adiponectin for the study group at the end of the treatment was statistically significant in comparison to baseline $(\mathrm{P}<0.05)$, as shown in Table 2.

The increase in the plasma adiponectin for the study group at the end of the treatment was significantly higher than in the control group $(\mathrm{P}<0.05)$, as shown in Table 2.

The decrease in the HbA1c for the control group at the end of the treatment was statistically not significant in comparison to baseline $(\mathrm{P}>0.05)$, as shown in Table 3.

The decrease in the HbA1c for the study group at the end of the treatment was statistically significant in comparison to baseline $(\mathrm{P}$ $<0.05$ ), as shown in Table 3 .

The decrease in the HbA1c for the study group at the end of the treatment was significantly higher than in the control group $(\mathrm{P}<$ 0.05), as shown in Table 3 .

There was negative significant correlation between plasma adiponectin and $\mathrm{HbA} 1 \mathrm{c}$ levels post treatment in the study group ( $\mathrm{r}$ $=-.787, \mathrm{p}=.000 * *)$, as shown in Table 4 and figure 1 .

Table 1: Demographic characteristics of the patients

\begin{tabular}{|l|c|c|c|}
\hline Characteristics & $\begin{array}{c}\text { control } \\
(\mathbf{n = 6 3})\end{array}$ & $\begin{array}{c}\text { study } \\
(\mathbf{n = 7 3})\end{array}$ & $\mathbf{p}$ \\
\hline Age (years, mean \pm SD) & $49.87 \pm 15$. & $53.63 \pm 13.99$ & .133 \\
\hline Sex (female/male) & $34 / 29$ & $39 / 34$ & .949 \\
\hline
\end{tabular}

Data are presented as mean $\pm S D$ or number of patients

Table 2: Plasma adiponectin levels between groups ug/mL.

\begin{tabular}{|l|c|c|c|}
\hline Characteristics & $\begin{array}{c}\text { Control } \\
(\mathbf{n = 6 3})\end{array}$ & $\begin{array}{c}\text { study } \\
(\mathbf{n = 7 3})\end{array}$ & $\mathbf{p}$ \\
\hline Baseline & $4.07 \pm .183$ & $4.12 \pm .22$ & .171 \\
\hline At the end of the treatment & $5 \pm .2$ & $5.75 \pm .14$ & $.000^{* *}$ \\
\hline
\end{tabular}

Data are presented as mean $\pm S D$ or number of patients. $* * P<$ 0.01
Table 3: Plasma HbA1c levels between groups.

\begin{tabular}{|l|c|c|c|}
\hline Characteristics & $\begin{array}{c}\text { Control } \\
(\mathbf{n = 6 3 )}\end{array}$ & $\begin{array}{c}\text { study } \\
(\mathbf{n = 7 3})\end{array}$ & $\mathbf{p}$ \\
\hline Baseline & $8.59 \pm .16$ & $8.75 \pm .05$ & $.000^{* *}$ \\
\hline At the end of the treatment & $8.37 \pm .1$ & $7.82 \pm .09$ & $.000^{* *}$ \\
\hline
\end{tabular}

Data are presented as mean $\pm S D$ or number of patients. $* * P<$ 0.01

Table 4: Bivariate correlation between plasma adiponectin and HbA1c levels post treatment in the study group.

\begin{tabular}{|c|c|}
\hline & HbA1c \\
\hline Adiponectin & $\mathrm{r}=-.787^{* *}$ \\
& $\mathrm{p}=.000$ \\
\hline
\end{tabular}

** Correlation is significant at the 0.01 level (2-tailed). p: probability value, $r$ : Pearson correlation

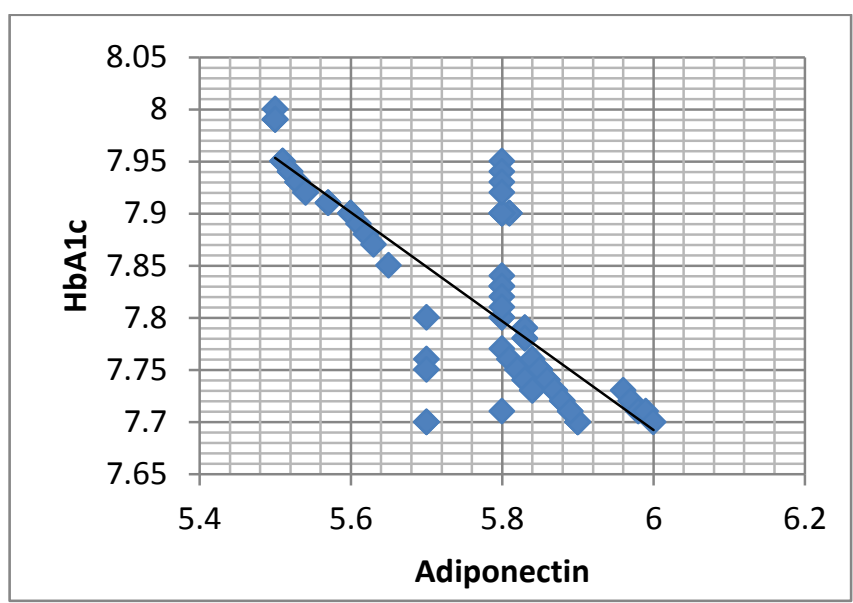

Figure (1): Scatter plot for the bivariate correlation between Plasma adiponectin and HbA1c levels post treatment in the study group.

\section{Discussion}

Adiponectin is a circulating adipocytokine which has antiinflammatory effect and closely related to cardiovascular disease, type 2 diabetes, and obesity. ${ }^{[2]}$

An acute bout of vigorous aerobic exercise can increase the plasma adiponectin levels in trained athletes. ${ }^{[10-11]}$

Kriketos et al. report that 2 to 3 bouts of aerobic exercise spread over one week increase the plasma adiponectin levels in inactive, abdominally obese men ${ }^{[2]}$

Adiponectin levels can be significantly decreased immediately following a bout of acute exercise. ${ }^{[3]}$

Our results agree with Kriketos et al., 2004 who reported individual changes in adiponectin levels after two to three bouts $\left(\sim 1\right.$ week) and after 10 weeks of exercise ${ }^{[2]}$

The results of the current study disagree with Saunders et al 2012 who reported that adiponectin levels can be significantly increased 30 minutes after the cessation of exercise, as well as after one week of aerobic training. ${ }^{[3]}$

Exercising at $75 \%$ of $\mathrm{VO} 2$ peak would have a greater impact on adiponectin levels than exercising at $50 \%$ of $\mathrm{VO} 2$ peak $^{[3]}$ 
In contrast to our results, the increase of plasma adiponectin after an acute bout of vigorous aerobic exercise is not apparent until 30 minutes after the cessation of exercise. ${ }^{[10-11]}$

Further, evidence also suggests that an acute bout of aerobic exercise at a moderate intensity has little or no impact on adiponectin levels in healthy, but untrained populations. ${ }^{[4]}$

In contrast to our results, immediately following the cessation of exercise, adiponectin levels are reported to be unchanged ${ }^{[10]}$ or even reduced ${ }^{[11]}$ in trained individuals.

Our results disagree with Hulver et al. who reported that adiponectin is unaltered with exercise training despite enhanced insulin action ${ }^{[12]}$

The results of the present study agree with Eriksson et al., reported that three months of moderate-intensity circuit resistance training significantly decreased HbAlc. ${ }^{[13]}$

A greater reduction in $\mathrm{HbA} 1 \mathrm{c}$ was observed in the training group compared to weight loss alone in a non-exercising control group ${ }^{[14]}$ Aerobic exercise has significant reduction on $\mathrm{HbA1} \mathrm{c}^{[15]}$

The results of the current study disagree with Honkola et al., who demonstrated that 5 months of progressive circuit resistance training did not result in a significant reduction in HbA1c. ${ }^{[16]}$

In conclusion, moderate intensity aerobic exercise training is an approach that has positive effects on improving type 2 diabetes. So; moderate intensity aerobic exercise training is is recommended to be added to the treatments of type 2 diabetes to improve the plasma adiponectin, HbA1c levels, the glycemic control and insulin sensitivity in patients with type 2 diabetes.

Acknowledgements The author would like to thank the study participants for their time and effort and Prof. Dr. Khalid Gamal Mahgoub (Director of Fitness and Rehabilitation unit, Department of Occupational and Environmental Medicine, Cairo University) for his support.

\section{References:}

[1] Pierard M, Conotte S, Tassin A, Boutry S, Uzureau P,Z Boudjeltia $\mathrm{K}$ et al.,: Interactions of exercise training and high-fat diet on adiponectin forms and muscle receptors in mice. Nutrition \& Metabolism. 2016, 13:75.

[2] Kriketos A D, Gan S K, Poynten A M, Furler S M, Chisholm D J., and Campbell L V: Exercise Increases Adiponectin Levels and Insulin Sensitivity in Humans. Diabetes Care. 2004, 27(2): 629-630.

[3] Saunders T J., Palombella A, McGuire K. A, Janiszewski P M., Després J P, and Ross R: Acute Exercise Increases Adiponectin Levels in Abdominally Obese Men. Journal of Nutrition and Metabolism. 2012, Article ID 148729, 6 pages.

[4] Simpson K A, Maria A. and Singh F: Effects of Exercise on Adiponectin: A Systematic Review obesity a research journal. 2008, Volume16, Issue2 Pages 241-256.

[5] Numao S., Katayama Y., Hayashi Y., Matsuo T., and Tanaka K.: "Influence of acute aerobic exercise on adiponectin oligomer concentrations in middleaged abdominally obese men," Metabolism. 2011, vol. 60, no. 2, pp. 186-194. View at Publisher · View at Google Scholar · View at Scopus.

[6] Jamurtas A. Z., Theocharis V. and Koukoulis G.: "The effects of acute exercise on plasma adiponectin and resistin levels and their relation to insulin sensitivity in overweight males," European Journal of Applied Physiology. 2006, vol. 97, no. 1, pp. 122126. View at Publisher View at Google Scholar View at Scopus.

[7] Ferland A, Broderick TL, Nadeau A, Simard S, Martin J, Poirier P: Impact of fasting and postprandial state on plasma carnitine concentrations during aerobic exercise in type 2 diabetes.Acta Diabetol. 2007, 44(3):114-120.

[8] Boule NG, Haddad E, Kenny GP, Wells GA, Sigal RJ: Effects of exercise on glycemic control and body mass in type 2 diabetes mellitus: a meta-analysis of controlled clinical trials. JAMA. 2001, 286:12181227.

[9] Zanuso S, Jimenez A., Pugliese G., Corigliano G. and Balducci S: Exercise for the management of type 2 diabetes: Acta Diabetol. 2010, 47:15-22.

[10] Hofmann J., P. and Jürimäe T.: "Plasma adiponectin response to sculling exercise at individual anaerobic threshold in college level male rowers," International Journal of Sports Medicine. 2006, vol. 27, no. 4, pp. 272-277. View at Publisher - View at Google Scholar · View at Scopus.

[11] Purge J., P., and Jürimäe T.: "Adiponectin is altered after maximal exercise in highly trained male rowers," European Journal of Applied Physiology. 2005, vol. 93, no. 4, pp. 502-505. View at Publisher · View a Google Scholar · View at Scopus.

[12] Hulver MW, Zheng D, Tanner CJ, Houmard JA, Kraus WE, Slentz CA et al.,: Adiponectin is not altered with exercise training despite enhanced insulin action. Am J Physiol. 2002, 283:E861-E865.

[13] Eriksson J, Taimela S, Eriksson K, Parviainen S, Peltonen $\mathbf{J}$ and Kujala $\mathbf{U}$ : Resistance training in treatment of non-insulindependent diabetes mellitus. Int J Sports Med. 1997, 18:242-246.

[14] Castaneda C, Layne JE, Munoz-Orians L, Gordon PL, Walsmith J, Foldvari $M$ et al.,: A randomized controlled trial of resistance exercise training to improve glycemic control in older adults with type 2 diabetes. Diabetes Care. 2002, 25:23352341.

[15] Kelley GA and Kelley KS: Effects of aerobic exercise on lipids and lipoproteins in adults with type 2 diabetes a metaanalysis of randomized-controlled trials. Public Health. 2007, 121(9):643-655.

[16] Honkola A, Forsen T, Eriksson J: Resistance training improves the metabolic profile in individuals with type 2 diabetes. Acta

[17] Diabetol. 1997, 34:245-248. 